\title{
A Horsehair Worm, Gordius sp. (Nematomorpha: Gordiida), Passed in a Canine Feces
}

\author{
Eui-Ju Hong ${ }^{1}$, Cheolho Sim², Joon-Seok Chae ${ }^{3}$, Hyeon-Cheol Kim, Jinho Park ${ }^{5}$, Kyoung-Seong Choi ${ }^{6}$, \\ Do-Hyeon Yư , Jae-Gyu Yoo ${ }^{8}$, Bae-Keun Park',*

\begin{abstract}
${ }^{1}$ College of Veterinary Medicine, Chungnam National University, Daejeon 35015, Korea; ${ }^{2}$ Department of Biology, Baylor University, Waco, Texas National University, Sangju 37224, Korea; ${ }^{7}$ College of Veterinary Medicine, Chonnam National University, Gwangju 61186, Korea; ${ }^{2}$ Laboratory of Veterinary Clinics, National Institute of Animal Science Rural Development Administration, Gwangju 61186, Korea
\end{abstract} \\ 76798, USA; ${ }^{2}$ Laboratory of Veterinary Internal Medicine, BK21 PLUS Program for Creative Veterinary Science Research and College of Veterinary \\ Medicine, Seoul National University, Seoul 03080, Korea; ${ }^{4}$ College of Veterinary Medicine, Gangwon National University, Chuncheon 24289, Korea; \\ ${ }^{5}$ College of Veterinary Medicine, Chonbuk National University, Cheongju 28644, Korea; ${ }^{6}$ College of Ecology and Environmental Science, Kyungpook
}

\begin{abstract}
Nematomorpha, horsehair or Gordian worms, include about 300 freshwater species in 22 genera (Gordiida) and 5 marine species in 1 marine genus (Nectonema). They are parasitic in arthropods during their juvenile stage. In the present study, the used gordian worm was found in the feces of a dog (5-month old, male) in July 2014. Following the worm analysis using light and scanning electron microscopes, the morphological classification was re-evaluated with molecular analysis. The worm was determined to be a male worm having a bi-lobed tail and had male gonads in cross sections. It was identified as Gordius sp. (Nematomorpha: Gordiidae) based on the characteristic morphologies of cross sections and areole on the cuticle. DNA analysis on $18 \mathrm{~S}$ rRNA partial sequence arrangements was also carried out, and the gordiid worm was assumed to be close to the genus Gordius based on a phylogenic tree analysis.
\end{abstract}

Key words: Gordius, horsehair worm, Nematomorpha, dog, Korea

\section{INTRODUCTION}

Juvenile horsehair or gordian worms (Nematomorpha) are obligate parasites of terrestrial insects and, as adults, are freeliving in freshwater sites including lakes, streams, and rivers $[1,2]$. After the larval stage, adult worms kill and leave the host for the beginning of the free-living stage [3]. Nematomorpha include about 300 freshwater species in 22 genera (Gordiida) and 5 marine species in 1 marine genus (Nectonema) [4].

Even though terrestrial insects act as a host, there are some reports on the presence of Nematomorpha in frogs, fishes, birds, and mammals including human beings [3,5]. However, mammalian parasitism of gordian worms is uncommon in the literature, although many gordian worms have been identified in different parts of the world from specimens recovered from the mouth, urethra, and anus [6-9]. To date, a total of 9 species in 3 genera have been recorded in the gordioidean fau-

- Received 20 March 2015, revised 7 September 2015, accepted 9 September 2015.

*Corresponding author (bkpark@cnu.ac.kr)

(c) 2015, Korean Society for Parasitology and Tropical Medicine

This is an Open Access article distributed under the terms of the Creative Commons Attribution Non-Commercial License (http://creativecommons.org/licenses/by-nc/3.0) which permits unrestricted non-commercial use, distribution, and reproduction in any

medium, provided the original work is properly cited. na in Korea [10-12]. Although the distribution and identification for gordian worms have been studied, there still remained a lot of undefined gordian worms.

This study deals with a Gordius sp. (Nematomorpha: Gordiida) passed in a canine feces in Korea. For identification of the gordian worm, it was studied by light, scanning, and transmission electron microscopes, and the morphological classification was re-evaluated with molecular analysis.

\section{CASE DESCRIPTION}

In Nonsan-si, Chungcheongnam-do, a gordian worm was passed in the feces of a cat (5-month old, male) which was alive and wiggling vigorously at that time (Fig. 1). The worm was placed in lacto-phenol solution (glycerin $20 \mathrm{ml}$, lactic acid $10 \mathrm{ml}$, phenol $10 \mathrm{ml}$, and distilled water $10 \mathrm{ml}$ ) for $24 \mathrm{hr}$ and tentatively identified under a light microscope.

For scanning electron microscopy (SEM), the pieces of parasite was washed 5 times with $0.2 \mathrm{M}$ cacodylate buffer ( $\mathrm{pH} 7.3$ ) and fixed in $2.5 \%$ glutaraldehyde, post-fixed in $1 \%$ osmium tetroxide at $4{ }^{\circ} \mathrm{C}$. The specimens were then dehydrated in a graded ethyl alcohol series, dried by a $\mathrm{CO}_{2}$ critical point dryer, coated with osmium, and examined by a SEM (S-4800, Hita- 

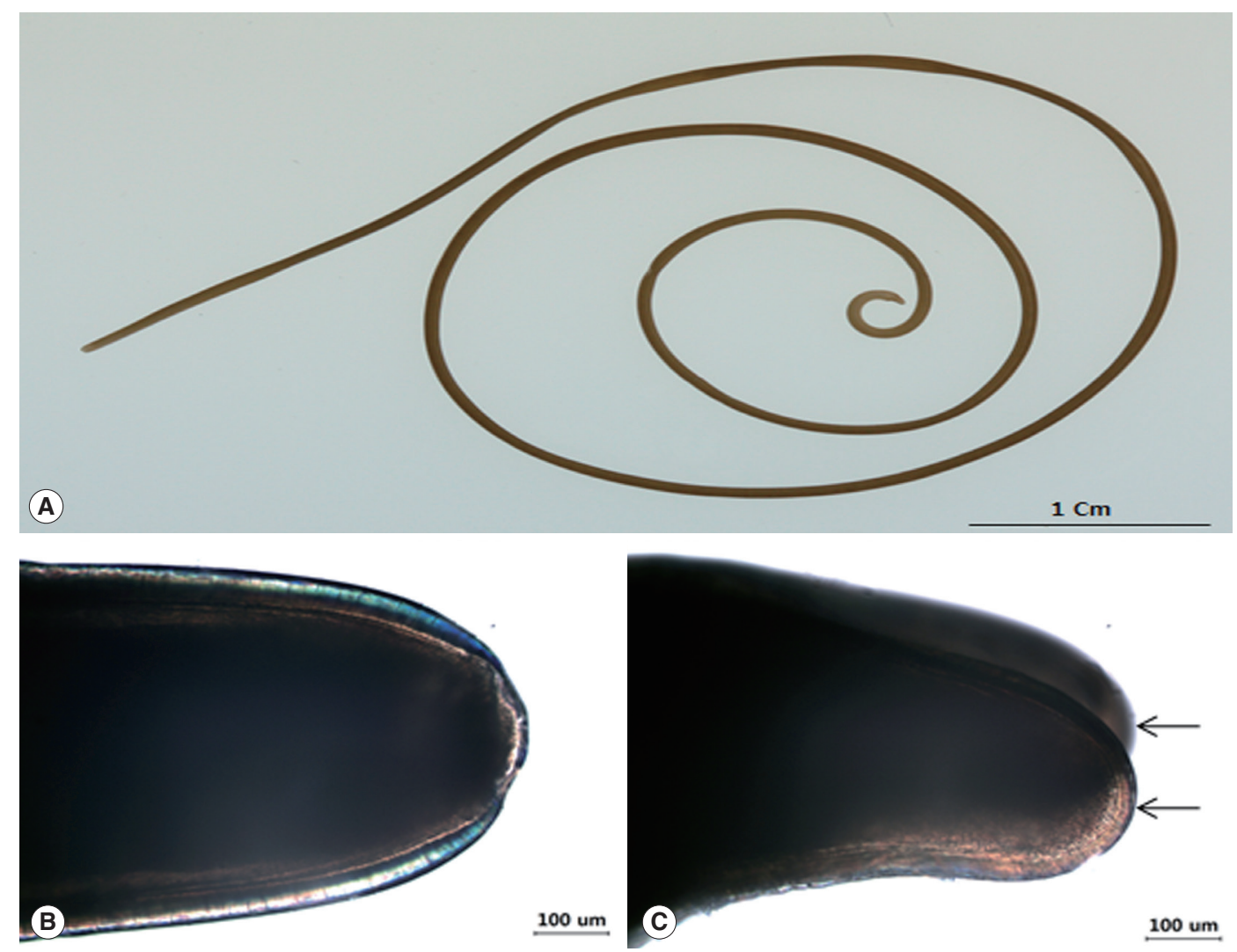

Fig. 1. Gross and light microscopic features of Gordius sp. (A) Gross finding of the worm. (B) The rounded calotte. (C) The posterior end. Tail is divided into 2 lobes (arrows).

chi, Ibaraki, Japan) at an accelerating voltage of $15 \mathrm{kV}$.

For the DNA extraction and amplification, the genomic DNA was extracted from the gordian worm by using a DNeasy ${ }^{\circledR}$ Blood and tissue kit (Qiagen, Alameda, California, USA) according to the manufacturer's instructions. Several sequences from Gordius albopunctatus, Gordius aquaticus, and Gordius paranensis were aligned using Multiple Sequence Alignment (Clustal Omega, http://www.ebi.ac.uk/Tools/msa/clusta$\mathrm{lo} /$ ), and then common Gordius primers were designed using the online tool (Primer3input, http://primer3.ut.ee/). An $18 \mathrm{~S}$ rRNA region spanning internal transcribed spacer 2 (ITS2) gene (DNA) was amplified for genomic DNA sequence using PCR. The oligonucleotide sequences of primers employed to detect Gordius 18S rRNA region spanning ITS2 gene (DNA), were 5'-GTCGTAACGGGTAACGGAGA-3' (forward) and 5'-TTTCGGACCAGGAGAATGAC-3' (reverse). The primer set were designed around 1,165 bp product, variable for all sequences aligned. Under standard condition such as $95^{\circ} \mathrm{C}$ for $30 \mathrm{sec}$, annealing at $60^{\circ} \mathrm{C}$ for $30 \mathrm{sec}$, and extension at $72^{\circ} \mathrm{C}$ for $1 \mathrm{~min}$, PCR reaction was performed in a MyCycler Personal
Thermal Cycler (Bio-Rad Laboratories, Hercules, California, USA) using EmeraldAmp GT PCR Master Mix (Takara, Shiga, Japan) with $1 \mu \mathrm{l}$ DNA aliquot. The PCR products were next visualized via electrophoresis on $1.2 \%$ agarose gel, and then purified using QIAquick PCR purification kit (Qiagen).

For the PCR sequence analysis, amplifications were directly sequenced using ABI Prism Big Dye terminator (v. 3.0) ready reaction cycle sequencing kits (Applied Biosystems, Foster City, California, USA) with the same primers as those used in PCR. The sequencing reactions were run on a PE Applied Biosystems 3100 automated sequencer. The sequence data were aligned by Clustal Omega program (clustal O 1.2.1). A phylogenetic tree-based sequence analysis was conducted by neighbor-joining using the blast tree program (http://blast.ncbi. nlm.nih.gov/Blast.cgi).

In gross findings, the body was $19.5 \mathrm{~mm}$ in length and 1.0 $\mathrm{mm}$ in diameter (Fig. 1A), and its color was light brown. In more details, the anterior end (calotte) was rounded with dark color, and the mouth was presented at the center (Fig. 1B), but the white tips were not found on the cuticle. The posterior end 

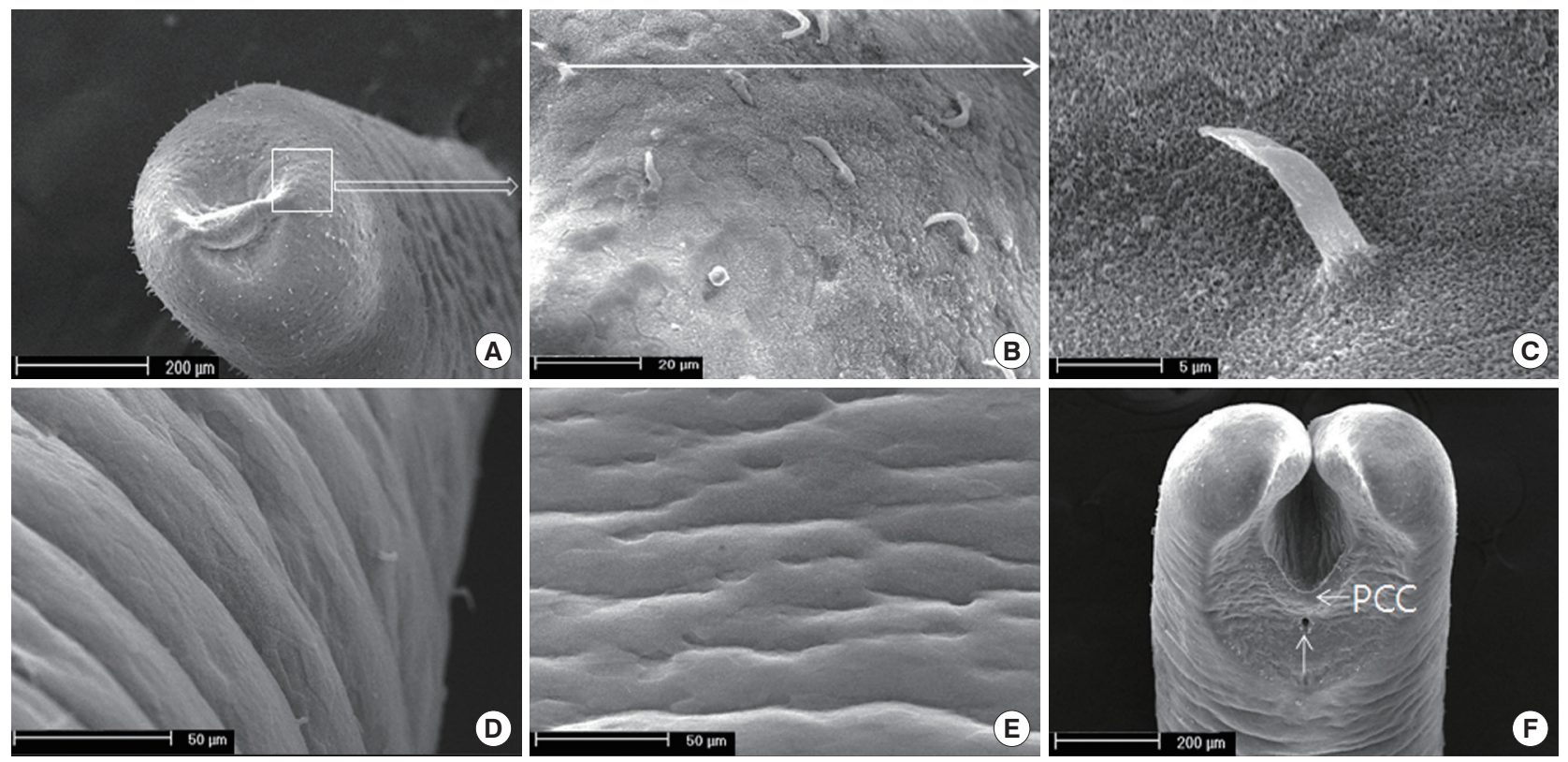

Fig. 2. SEM finding of Gordius sp. cuticle. (A) Anterior part of the worm. Note the areoles on the cuticle. (B) The magnified square in (A). Spines are scattered on the anterior end. (C) A single spine. (D) The lateral view of the mid-body. Note the areoles found rarely. (E) The ventral view of the mid-body. Spines are not found. (F) Ventral view on the posterior end of a male with V-shaped postcloacal crescent and semicircular row of bristles. Note that the tails are bi-lobed and the inverted V-shaped ridge is containing the bristle. The postcloacal crescent (PCC) is located behind the cloaca (arrow).

was bi-lobed with blunt lobes, with each lobe about twice as long as wide (Fig. 1C). The cuticle was smooth and slippery.

Using SEM analysis, the cuticle structure was not shown as the elevated (increased or high) cuticular areoles on the surface of the body, but the spines on the cuticles of the anterior portion were sseen (Fig. 2A-C). While hairs were found on the anterior portion, it was difficult to find spines in the midbody, as shown in Fig. 2D and E. The cuticular areoles appeared slightly on the anterior portion. The distinct crescentshaped fold was located behind the cloaca, and the inverted Vshaped ridge containing some bristle was anterior to the cloaca (Fig. 2F). Interestingly, male tail lobes were 2 times shorter than their diameter. The post-cloacal crescent was semicircular, with the width of about $200 \mu \mathrm{m}$, which was about $50 \%$ of the width of the posterior end at the level of the crescent (Fig. 2F). During the tail lobes branched directly behind the postcloacal crescent, the bristles on the tail lobe were rare. The arms of the crescent do not extend onto the tail lobes (Fig. 2F).

To identify the genotype of the used Gordius specimens, its genomic DNA was analyzed by the sequencing method. The ITS2 region of $18 \mathrm{~S}$ rRNA in Gordius specimens was identified and compared with that of G. albopunctatus (U99337.1), G. aquaticus (X80233.1), and G. paranensis (AF421766.1), respec- tively. As a PCR amplicon, partial ITS2 sequences (1,097 bp) of the Gordius specimens contained 38 variable sites of common sequence in which belonged to the same clade as G. albopunctatus, G. aquaticus, and G. paranensis, respectively. The sequence of Gordius specimens was shown with high similarity in G. albopunctatus (97.6\%), G. aquaticus (97.6\%), and G. paranensis $(97.1 \%)$, respectively. Furthermore, partial ITS2 sequences of the Gordius specimens reveal the low gap difference of nucleotide in G. albopunctatus (0.7\%), G. aquaticus (1.0\%), and G. paranensis (0.8\%), respectively. Although 5 DNA regions of Gordius specimens was not matched with above sequences of the 3 Gordius sp., the identification was also supported by the fact that they belonged to the same clades as Gordius in the phylogenetic tree based on the used ITS2 rRNA gene. When the sequence of Gordius specimens was compared with genes from several horsehair worms, the sequence data was inferred using the neighbor-joining method. The sequence of Gordius specimens was identified as a species that is genetically close to the Gordius species (U88337.1, X87985.1, X80233.1, AB470227.1, AF421766.1, U51005.1, AY863409.1), Paragordius species (AY428819.1, AF421771.1, AF421770.1, AF421769.1), and Chordoes species (AF421763.1, AF036639.1) (Fig. 3). 


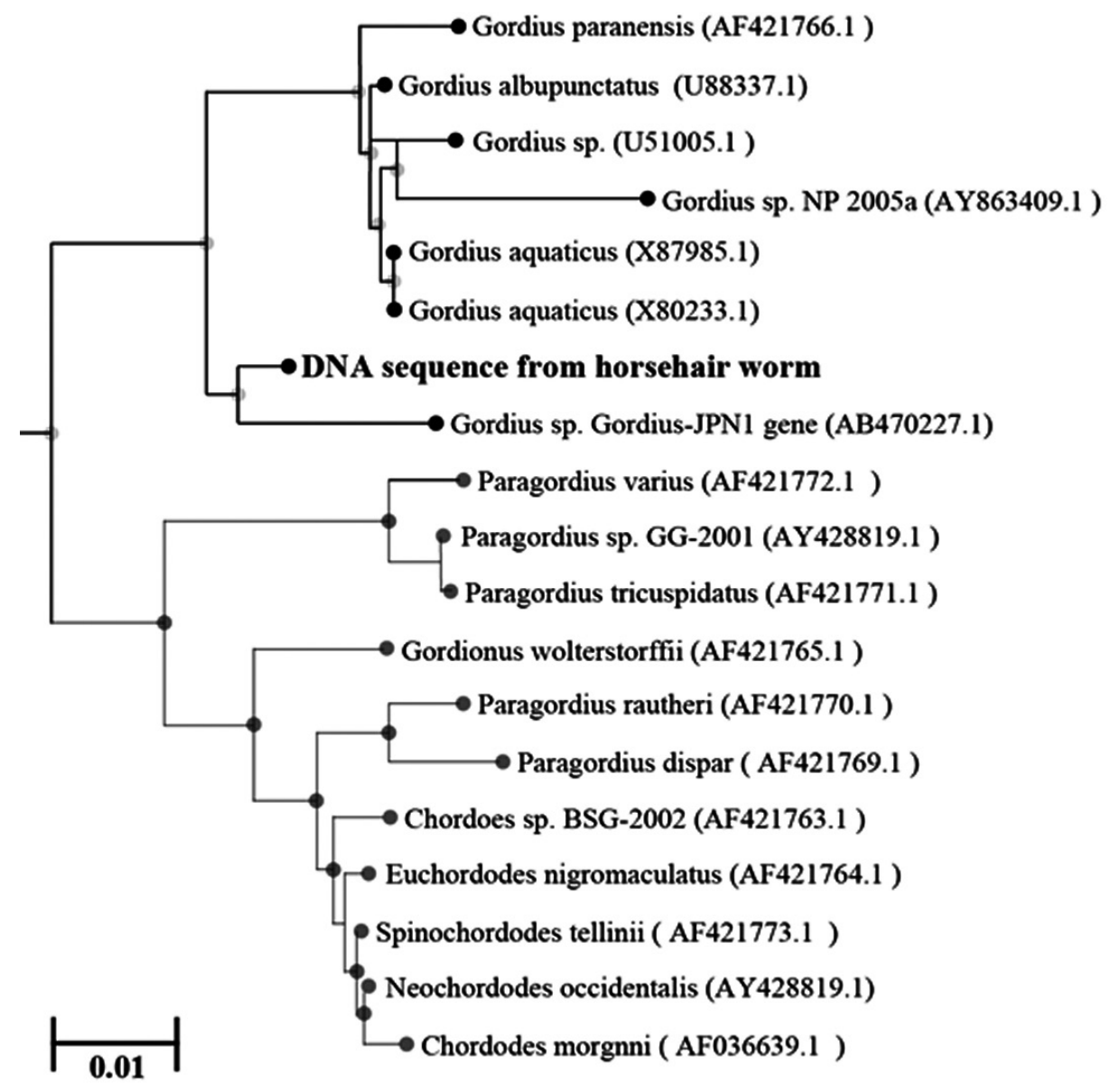

Fig. 3. Phylogenetic tree (neighbor-Joining) based on sequence analysis.

\section{DISCUSSION}

The class Gordiacea includes 2 recognized families, Gordiidae and Chordodidae. The members of Gordiidae have a smooth cuticle, even though the areoles in some species of Gordiidae occur. The cuticle in Chordodidae is rough with true areoles. These subfamily groups include 18 genera (Chordodes, Paragordius, Parachordodes, Neochordodes, Pseudogordius, and others). There are also other genera with 2 types of areoles, but the characteristic for Parachordodes is that 1 of the 2 types is very large and has a pore on the top. This type is called a superareole [13].

The traditional classification includes 4 families: Gordiidae including genera with a so-called postcloacal crescent (Gordius and Acutogordius), Spinochordodidae including the genus Spinochordodes, Lanochordodidae including the monotypic genus Lanochordodes, and Chordodidae including all remaining genera [4]. The genus Chordodes is the largest genus of Nemato- morpha with about 90 described species [14]. A semicircular or parabolic crescent posterior to the cloacal opening in males (i.e., the postcloacal crescent) characterizes the genus Gordius. This structure is also present in the South American and Southeast-Asian genus Acutogordius, which is easy to distinguish from Gordius by the possession of pointed tail lobes in the male. The diagnostic features of nematomorphs include the shape of the posterior end and cuticular structures. These structures are most reliably documented with SEM, which is the primary tool in gordiid taxonomy. Also, light microscopy of cuticular structures is still necessary and important [15].

Gordius species often lack diagnostic characters in addition to the postcloacal crescent. In more details, the male posterior end usually lacks bristles or spines, and several species have a smooth cuticle without areoles. For some species, a rhomboidal pattern has been reported, which is due to the underlying cuticular fibers arranged in crossed layers where fibers of adjacent layers form an angle. White spots on the cuticle are also a 
common pattern, but the latter is not a reliable diagnostic feature [16]. In our case, the areoles were slightly shown at anterior and posterior portions, but the white spots were not found.

In Korea, 2 species of Gordius (G. robustus and G. lineatus) have been previously reported [11]. G. lineatus (now Gordionus lineatus) is easily distinguished by characteristics of its dorsal and ventral lines. This worm resembles $G$. aquaticus because it does not possess a row of hairs around the male cloacal aperture, but differs from G. robustus and G. aquaticus which had wick areoles on the surface of cuticles. Moreover, G. lineatus is similar to G. robustus in that it has short hairs over the whole body cuticle, especially anterior and posterior portions.

Many studies have been done on the ultrastructure of the cuticles of gordiids. However, no agreement has been reached on naming the different strata that compose it. Swanson [17] described the 2 components of the cuticle (homogeneous and fibrous layers) in his work on Paragordius varius and G. robustus. Zapotosky [18] described 3 main cuticular layers (the cortex, areolar, and basal, which are in turn subdivided into sublayers) in his work on P. varius. Bresciani $[19,20]$, when referring to G. aquaticus, determined the presence of 2 cuticular layers, the protective and fibrillar components. Eakin and Brandenburger [21], working on an unnamed Gordius sp., also found 2 layers, these being the epicuticle and the fibrillar cuticle. In our study, the cuticle consists of 3 layers, the epicuticle, germinal layer, and fibrillar layer.

The worms have been occasionally reported in humans, but hardly ever in domestic animals. A mammalian case of a Gordius worm passed the worm through the anus or vomited it out, and another case of a Parachordodes worm in the urinary system has also been reported in Korea [1,12]. In Japan, Saito et al. [8] reported a hairworm vomited by a domestic cat. Although the worm seemed to be similar to Gordius ogatai, it could not be readily identified as G. ogatai [8]. Furthermore, a male worm of Chododes koreensis was reported in the canine vomitus in Korea [22].

As a nuclear ribosomal DNA, ITS2 sequence of 18S rRNA gene was used to study inter- and intra-specific relationships because it is highly repeated and contains variable regions flanked by more conserved regions [23]. Furthermore, ITS2 sequence has been used for diagnostic purposes at the level of species [24-26]. For example, ITS2 sequences have been used to characterize the liver flukes as a specific marker [27]. Following above evidences, we assessed the Gordius specimens using molecular approaches. Although the low genetic diver- gence of Gordius specimens suggests their conspecific relationship with other Gordius sp., sequence data of Gordius specimens could be separated from the genetic information of those hairworms such as G. albopunctatus, G. aquaticus, and G. paranensis.

In our study, the post-cloacal crescent was located behind the cloaca and inverted V-shaped ridge containing bristle anterior at the cloaca. DNA analysis of $18 S$ rRNA partial sequence arrangements was carried out, and the gordiid worm was assumed to be close to G. albopunctatus or G. aquaticus based on the tree analysis. However, sequencing alignment and phylogeny is not enough to conclude that this worm is G. albopunctatus or G. aquaticus, since homology in the sequences had similarity with 97.1-97.6\% among the 3 species of Gordius.

\section{ACKNOWLEDGMENT}

This work was supported by a research fund of Chungnam National University (no. 2014-0652-01).

\section{CONFLICT OF INTEREST}

We have no conflict of interest related to this work.

\section{REFERENCES}

1. Schmidt-Rhaesa A, Hanelt B, Reeves WK. Redescription and compilation of Nearctic freshwater Nematomorpha (Gordiida), with description of two new species. Proceed Acad Nat Sci Philadelphia 2003; 153: 77-117.

2. Poinar G Jr, Rykken J, LaBonte J. Parachordodes tegonotus n. sp. (Gordioidea: Nematomorpha), a hairworm parasite of ground beetles (Carabidae: Coleoptera) with a summary of gordiid parasites of carabids. Syst Parasitol 2004; 58: 139-148.

3. Brivio MF, de Eguileor M, Grimaldi A, Vigetti D, Valvassori R, Lanzavechia G. Structural and biochemical analysis of the parasite Gordius villoti (Nematomorpha, Gordiacea) cuticle. Tissue Cell 2000; 32: 366-376.

4. Bleidorn C, Schmidt-Rhaesa A, Garey JR. Systematic relationships of Nematomorpha based on molecular and morphological data. Invertebr Biol 2002; 121: 357-364.

5. Bolek MG, Coggins JR. Seasonal occurrence, morphology, and observations on the life history of Gordius difficilis (Nematomorpha: Gordioidea) from southeastern Wisconsin, United States. J Parasitol. 2002; 88: 287-294.

6. AliKhan FE, AliKhan Z. Paragordius varius (Leidy) (Nematomorpha) infection in man: a case report from Quebec (Canada). J Parasitol 1977; 63: 174-176. 
7. Wei DX, Yang WY. Parachordodes sp. (Nematomorpha) human infestation of the lower urinary tract: the first case report in China. Acta Acad Med Wuhan 1981; 1: 40-45.

8. Saito Y, Inoue I, Hayashi F, Itagaki H. A hairworm, Gordius sp., vomited by a domestic cat. Nihon Juigaku Zasshi 1987; 49: 1035-1037.

9. Herter CD, Nesse RE. Pseudoparasitism with Gordius robustus. Am Fam Physician 1989; 39: 139-142.

10. Baek KM. Two species of genus Chordodes (Gordioidae, Nematomorpha) from Korea. Korean J Syst Zool 1993; 9: 221-228.

11. Baek KM, Noh YT. Two species of genus Gordius (Gordioidae, Nematomorpha) from Korea. Korean J Syst Zool 1992; 8: 223230.

12. Lee KJ, Bae YT, Kim DH, Deung YK, Ryang YS, Im KI, Yong TS. Gordius worm found in a three year old girl's vomitus. Yonsei Med J 2003; 44: 557-560.

13. Schmidt-Rhaesa A. Australian species of Chordodes (Nematomorpha) with a description of two new species, remarks on the genus Chordodes and its life history. J Natural History 2002; 36: 1569-1588.

14. Schmidt-Rhaesa A, Menzel L. Central American and Caribbean species of horsehair worms (Nematomorpha), with the description of three new species. J Natural History 2005; 39: 515-529.

15. SchmidtRhaesa A, Chung PR, Sohn WM. Parachordodes megareolatus, a new species of horsehair worm (Nematomorpha: Gordioida: Gordea) from Korea. Korean J Syst Zool 2003; 19: 161-166.

16. Schmidt-Rhaesa A. Nematomorpha. In Schwoer-bel J, Zwick P (eds), Süßwasserfauna von Mitteleuropas, Vol. 4/4. Gustav Fischer Verlag, Stuttgart. 1997; p 124.

17. Swanson CJ. Occurrence of paramyosin among the Nematomorpha. Nat New Biol 1971; 232: 122-123.

18. Zapotosky JE. The cuticular ultrastructure of Paragordius varius
(Leidy 1851) (Gordioidea, Paragordidae). Proc Helminthol Soc Washington 1971; 38: 228-236.

19. Bresciani J. The integument of Gordius aquaticus Duj (Nematomorpha, Gordioidea). R Vet Agric Univ Yearb Copenhagen 1970: 92-96.

20. Bresciani J. Nematomorpha. In Harrison FW, Ruppert EE (eds), Microscopic anatomy of invertebrates, Vol. 4. Aschelminthes. New York, USA. Wiley-Liss. 1991; 197-218.

21. Eakin RM, Brandenburger JL. Ultrastructural features of a gordian worm. J Ultrastruct Res 1974; 46: 351-374

22. Son HY, Chae JS, Kim HC, Park BK. Morphological study of the horsehair worm, Chordodes koreensis (Nematomorpha: Gordiida), isolated in canine vomitus. J Vet Clin Med (Korea) 2009; 26: 348-352.

23. Hillis DM, Dixon MT. Ribosomal DNA: molecular evolution and phylogenetic inference. Q Rev Biol 1991; 66: 411-453.

24. Morgan JA, Blair D. Nuclear rDNA ITS sequence variation in the trematode genus Echinostoma: an aid to establishing relationships within the 37-collar spine group. Parasitology 1995; 111: 609-615.

25. Léon-Règagnon V, Brooks DR, Pérez-Ponce de Leon G. Differentiation of Mexican species of Haematoloechus Looss, 1899 (Digenea: Plagiorchiformes): molecular and morphological evidence. J Parasitol 1999; 85: 935-946.

26. Huang WY, He B, Wang CR, Zhu XQ. Characterisation of Fasciola species from Mainland China by ITS-2 ribosomal DNA sequence. Vet Parasitol 2004; 120: 75-83.

27. Prasad PK, Tandon V, Biswal DK, Goswami LM, Chatterjee A. Molecular identification of the Indian liver fluke, Fasciola (Trematoda: Fasciolidae) based on the ribosomal internal transcribed spacer regions. Parasitol Res 2008; 103: 1247-1255. 